\title{
FORMULASI STRATEGI PADA PT INTAN DUA
}

\author{
Rudy Vernando Silalahi ${ }^{1}$, Eric Jobiliong, Ph.D ${ }^{2}$, Huanche Wilson ${ }^{3}$ \\ 1,2,3Program Studi Teknik Industri, Fakultas Sains dan Teknologi \\ Universitas Pelita Harapan \\ Jl. MH. Thamrin Boulevard 1100, Lippo Village. \\ e-mail: rudy.silalahi@uph.edu
}

\begin{abstract}
Abstrak
Strategi pemasaran adalah pola pikir pemasaran yang digunakan untuk mencapai tujuan pemasarannya. Pada PT Intan Dua, penerapan strategi pemasaran masih belum tepat, dapat dilihat dari penurunan tingkat penjualan pakaian oblong PT Intan Dua. Dalam upaya meningkatkan tingkat penjualan pakaian oblong PT Intan Dua, maka dilakukan formulasi strategi pemasaran PT Intan Dua. Agar proses formulasi strategi pemasaran pada PT Intan Dua menjadi lebih efektif, dilakukan penelitian secara langsung pada PT Intan Dua. Penelitian dimulai dari pengumpulan data-data bauran pemasaran PT Intan Dua. Setelah itu, dibuatlah faktor-faktor internal dan eksternal yang berkaitan dengan bauran pemasaran PT Intan Dua. Faktor internal akan dinilai konsumen, yaitu reseller PT Intan Dua, dan faktor eksternal akan dinilai pihak manajemen PT Intan Dua. Hasil yang didapat menunjukkan bahwa nilai skor tertimbang IFE sebesar 2.648, yang berarti kondisi internal perusahaan memiliki kekuatan yang lebih dominan. Hasil skor tertimbang EFE yang didapaat sebesar 2.464, yang berarti kondisi eksternal perusahaan memiliki ancaman yang lebih dominan. Dengan penilaian IFE dan EFE tersebut, kondisi perusahaan dapat diketahui terdapat pada kuadran II diagram cartesius SWOT. Strategi yang tepat untuk PT Intan Dua menurut kondisi perusahaan adalah strategi ST yang merupakan strategi diversifikasi matriks SWOT . Strategi ST berupa mempertahankan dan meningkatkan kualitas produk, membangun motivasi beli konsumen, dan membangun citra produk.
\end{abstract}

Kata Kunci: Strategi Pemasaran, Internal Factor Evaluation, External Factor Evaluation, Analisis SWOT.

\section{PENDAHULUAN}

Pesatnya perkembangan industri memicu tingginya tingkat persaingan antar perusahaan, tingginya tingkat persaingan antar perusahaan membuat kemampuan bertahan hidup suatu perusahaan menjadi lebih sulit. Setiap perusahaan, baik yang bergerak di bidang produk maupun jasa mempunyai tujuan untuk bertahan hidup dan berkembang, tujuan tersebut dapat dicapai dengan salah satu cara, yaitu mendapatkan tingkat keuntungan atau laba operasional perusahaan yang cukup. Untuk meningkatkan tingkat keuntungan perusahaan dapat diperoleh dengan meningkatkan penjualan produk atau jasa yang diproduksi oleh perusahaan. Strategi pemasaran adalah salah satu cara untuk meningkatkan tingkat penjualan perusahaan, oleh karena perlu di formulasikan strategi pemasaran yang tepat.

PT Intan Dua adalah perusahaan pembuat pakaian yang sudah berdiri lebih dari 60 tahun. Produk-produk pakaian yang dihasilkan oleh PT Intan Dua juga bermacam macam, seperti kaus oblong, kaus raglan, kaus tanpa lengan, kaus Polo, kaus Henley, dan juga kemeja. Seiring berjalannya waktu ada perubahan yang terjadi pada pakaian-pakaian yang diproduksi oleh PT Intan Dua, hal ini disebabkan oleh perubahan lingkungan dan minat konsumen, sehingga PT Intan Dua harus menyesuaikan dengan kebutuhan dan keinginan konsumen. Dalam studi pendahuluan yang dilakukan pada PT Intan Dua, didapati penjualan pakaian oblong mengalami penurunan. Setelah ditelusuri lebih lanjut sekitar 
85.8\% penjualan pakaian oblong PT Intan Dua berasal dari reseller. Penurunan ini diduga diakibatkan oleh kurangnya penerapan strategi-strategi pemasaran yang tepat dan sesuai oleh PT Intan Dua. Dengan adanya formulasi strategi pemasaran pada PT Intan Dua yang dikhususkan terhadap reseller sebagai konsumen major PT Intan Dua, diharapkan dapat meningkatkan tingkat penjualan pakaian oblong PT Intan Dua.

\section{KERANGKA KERJA TEORITIS}

Kerangka kerja teoritis merupakan diagram tentang tahapan-tahapan teoritis yang digunakkan dalam penelitian.

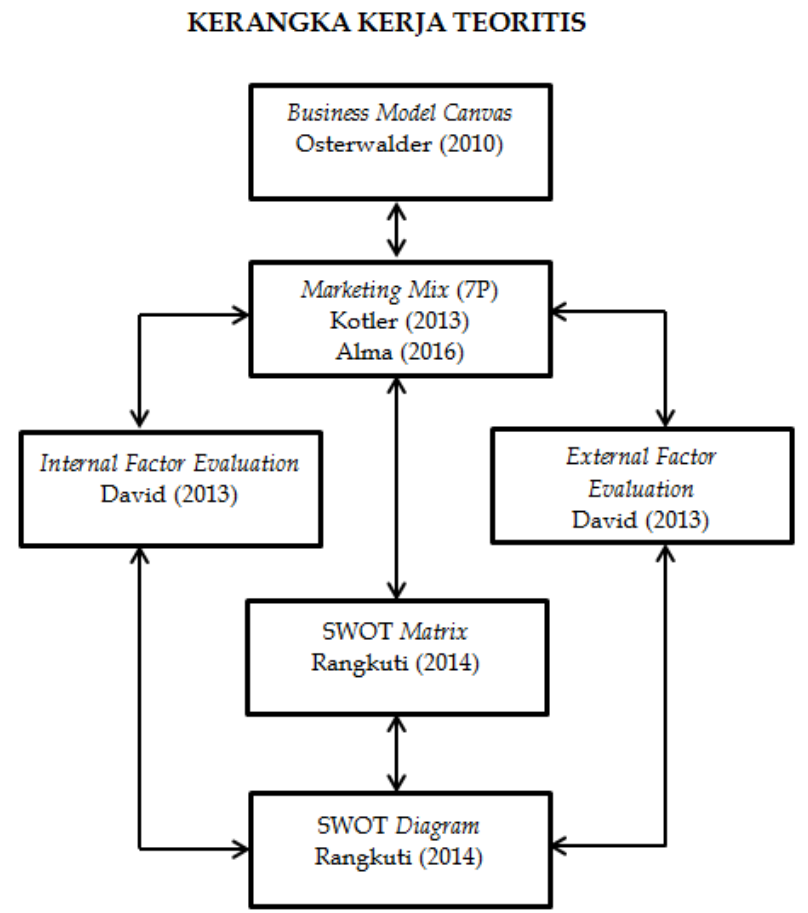

Gambar 1. Kerangka Kerja Teoritis

Osterwalder dan Pigneur (2010) menyebutkan pengertian Model Bisnis Kanvas adalah sebuah manajemen strategi bisnis yang memungkinkan untuk menggambarkan, mendesain kemudian mengerucutkan beberapa aspek bisnis menjadi satu startegi bisnis yang utuh. Business model canvas ditampilkan dalam sebuah kanvas yang terdiri dari 9 elemenKey activitie.

Tahapan dalam formulasi strategi pemasaran yang tepat bagi perusahaan dimulai dengan mencari aspek-aspek bauran pemasaran dari perusahaan, termasuk didalamnya $7 \mathrm{p}$ (product, price, place, promotion, people, process, physical evidence).

Produk menurut Kotler (2013) adalah : "A product is a thing that canbe offered to a market to satisfy a want or need". Produk adalah segala sesuatu yangdapat ditawarkan kepada pasar untuk memuaskan suatu keinginan atau kebutuhan konsumen. Didalam aspek bauran pemasaran produk terdapat 5 atribut, yaitu Design, Quality, Feature,Brand, dan Packaging.

Harga menurut Kotler (2013) adalah : "Price is the amount of moneycharged for a product or service”. Harga adalah sejumlah uang yang mempunyainilai tukar untuk memperoleh keuntungan dari memiliki atau menggunakan suatu produk atau jasa. Didalam 
aspek bauran pemasaran harga terdapat 4 atribut, yaitu List Price, Discount and Allowances, Payment Period, and Payment Method.

Tempat menurut Kotler (2013) adalah :"The various thecompany undertakes to make the product accessible and available to target customer". Tempat merupakan berbagai kegiatan yang dilakukan oleh perusahaanuntuk membuat produknya mudah diperoleh dan tersedia pada konsumen sasaran. Didalam aspek bauran pemasaran tempat terdapat 5 atribut, yaitu Location, Channel, Coverage, Inventory, Transportation and Logistics.

Promosi menurut Kotler (2013) adalah : "Promotion includes all theactivities the company undertakes to communicate and promote its product the target market". Promosi adalah semua kegiatan yang dilakukan perusahaan untukmengkomunikasikan dan mempromosikan produknya kepada pasar sasaran. Didalam aspek bauran pemasaran promosi terdapat 4 atribut, yaitu Advertising, Sales Promotion, Direct Marketing, dan Public Relation.

SDM (people) menurut Kotler (2013), yaitu proses seleksi, pelatihan, dan pemotivasian karyawan yang nantinya dapat digunakan sebagai pembedaan perusahaan dalam memenuhi kepuasan pelanggan. Didalam aspek bauran pemasaran SDM terdapat 3 atribut, yaitu Personal Selling, Customer Service, dan Training.

Bukti fisikmenurut Kotler (2013), yaitu bukti yang dimiliki oleh penyedia barang/jasa yang ditujukan kepada konsumen sebagai usulan nilai tambah konsumen. Didalam aspek bauran pemasaran bukti fisik terdapat 4 atribut, yaitu Physical Environment, Ambience, Spatial Layout, dan Corporate Branding.

Proses menurut Boom dan Bitner yang dikutip oleh Buchari Alma (2016), yaitu semua prosedur aktual, mekanisme dan aliran aktivitas dengan mana barang/jasa disampaikan yang merupakan sistem penyajian atas kegiatan operasi. Didalam aspek bauran pemasaran proses terdapat 4 atribut, yaitu Technological Process, Electronic Process, Direct Activites, dan Indirect Activites.

Menurut David (2013), matriks IFE adalah alat manajemen strategis untuk audit atau evaluasi kekuatan dan kelemahan perusahaan dalam bidang fungsional bisnis. Tujuannya adalah untuk melihat kuat atau lemahnya kondisi internal suatu perusahaan, sedangkan matriks EFE adalah alat yang baik untuk memvisualisasikan dan memprioritaskan peluang dan ancaman yang dihadapi bisnis. Tujuannya adalah untuk menilai kondisi peluang atau ancaman perusahaan saat ini.

Diagram SWOT digunakan untuk melihat kondisi perusahaan, dalam diagram SWOT terdapat 4 kuadran, yaitu kuadran I,II,III, dan IV. Diagram SWOT dilihat berdasarkan hasil nilai skor tertimbang matriks IFE dan EFE. (Rangkuti, 2014) 


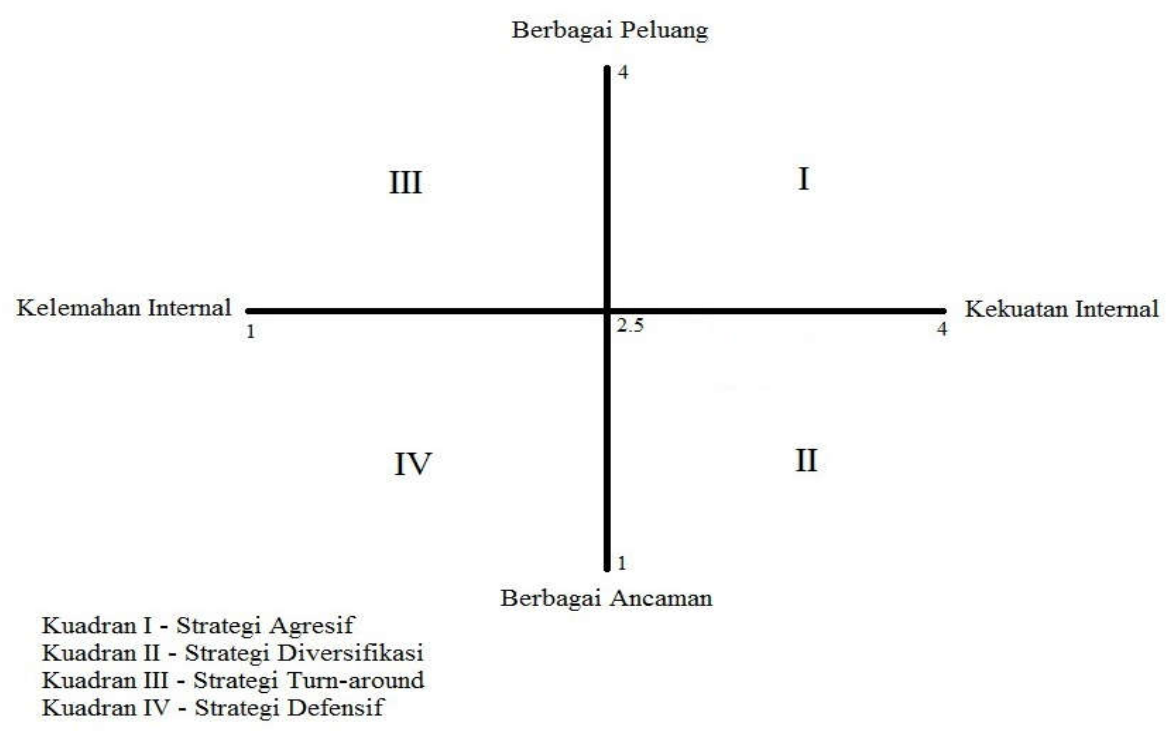

Gambar 2. Diagram SWOT

Setelah mendapatkan informasi tentang kondisi perusahaan, tahap selanjutnya adalah memanfaatkan semua informasi tersebut dalam model-model kuantitatif perumusan strategi. Salah satu modal yang dipakai untuk menyusun faktor-faktor strategi perusahaan adalah Matriks SWOT (Freddy Rangkuti, 2014)

Tabel 1. Matriks SWOT

\begin{tabular}{|c|l|l|}
\hline IFE & \multicolumn{1}{|c|}{$\begin{array}{c}\text { Strength (S) } \\
\text { Kekuatan Internal }\end{array}$} & \multicolumn{1}{c|}{$\begin{array}{c}\text { Weakness (W) } \\
\text { Kelemahan Internal }\end{array}$} \\
\hline $\begin{array}{l}\text { OpEortunities (O) } \\
\text { Peluang Eksternal }\end{array}$ & $\begin{array}{l}\text { Strategi SO } \\
\text { Ciptakan strategi yang menggunakan } \\
\text { kekuatan untuk memanfaatkan } \\
\text { peluang (Agresif) }\end{array}$ & $\begin{array}{l}\text { Strategi WO } \\
\text { Ciptakan strategi yang meminimalkan } \\
\text { kelemahan untuk memanfaatkan } \\
\text { peluang (Turn Around) }\end{array}$ \\
\hline $\begin{array}{l}\text { Threats (T) } \\
\text { Ancaman Eksternal }\end{array}$ & $\begin{array}{l}\text { Siptakan strategi yang menggunakan } \\
\text { kekuatan untuk menghindari ancaman } \\
\text { (Diversifikasi) }\end{array}$ & $\begin{array}{l}\text { Strategi WT } \\
\text { Ciptakan strategi yang meminimalkan } \\
\text { kelemahan dan menghindari ancaman } \\
\text { (Defensif) }\end{array}$ \\
\hline
\end{tabular}

\section{METODE PENELITIAN}

Tahapan di dalam melakukan formulasi strategi pemasaran pada PT Intan Dua sebagai berikut :

1. Membuat Business Model Canvas berdasarkan data-data marketing mix yang telah diperoleh, untuk mengetahui aspek bisnis perusahaan secara utuh.

2. Mengumpulkan informasi-informasi yang berkaitan dengan marketing mix (7p) perusahaan.

3. Membuat daftar faktor-faktor internal perusahaan yang berhubungan dengan datadata marketing mix (7p) perusahaan.

4. Melakukan assessment faktor internal perusahaan yang dilakukan oleh pihak eksternal. Pada penelitian ini pihak eksternal yang dimaksud adalah reseller.

5. Melakukan Evaluasi Faktor Internal dengan menggunakan IFE matrix berdasarkan faktor-faktor internal yang telah dinilai oleh pihak eksternal. 
6. Membuat daftar faktor-faktor eksternal perusahaan yang berhubungan dengan faktor-faktor internal dan marketing mix (7p) perusahaan.

7. Melakukan assessment faktor eksternal perusahaan yang dilakukan oleh pihak internal perusahaan.

8. Melakukan Evaluasi Faktor Eksternal dengan menggunakan EFE matrix berdasarkan faktor-faktor eksternal yang telah dinilai oleh pihak internal.

9. Melakukan analisis kondisi perusahaan dengan menggunakan data nilai skor tertimbang matriks IFE dan EFE yang diolah dengan menggunakan diagram SWOT.

10. Memformulasikan strategi pemasaran yang dapat diimplementasikan dan sesuai dengan kondisi perusahaan, dengan menggunakan matriks SWOT.

11. Membuat Business Model Canvas setelah adanya formulasii strategi pemasaran, untuk mengetahui ada atau tidaknya perubahan pada aspek bisnis perusahaan.

\section{HASIL DAN PEMBAHASAN}

Tahapan awal yang dilakukan adalah mengumpulkan informasi-informasi tentang marketing mix PT Intan Dua. Pada penelitian ini produk yang difokuskan adalah pakaian oblong, dan konsumen yang difokuskan adalah reseller.

\section{Business Model Canvas awal}

Business Model canvas awal dibuat untuk melihat keseluruhan aspek bisnis PT Intan Dua secara utuh.

\begin{tabular}{|c|c|c|c|c|}
\hline Business Model Canvas & $\begin{array}{l}\text { Designed for: } \\
\text { PT Intan Dua }\end{array}$ & $\begin{array}{l}\text { Designed by: } \\
\text { Huanche Wilson }\end{array}$ & $\begin{array}{c}\text { Date: } \\
26 / 12 / 18\end{array}$ & $\begin{array}{c}\text { Version } \\
1.0\end{array}$ \\
\hline $\begin{array}{l}\text { Key Partners } \\
\text { 1.Supplier Kain } \\
\text { 2.Toko Pakaian } \\
\text { 3.Jasa Pengiriman } \\
\text { 4.Reseller }\end{array}$ & \multirow{2}{*}{$\begin{array}{l}\text { Key Activites } \\
\text { Produksi } \\
\text { Pakaian: } \\
\text { 1.Beli Bahan } \\
\text { Baku } \\
\text { 2.Potong Pola } \\
\text { 3.Sablon } \\
\text { 4.Jahit } \\
\text { 5.Setrika } \\
\text { 6.Packing }\end{array}$} & $\begin{array}{l}\text { Customer } \\
\text { Segment } \\
\text { Konsumen kelas } \\
\text { menengah } \\
\text { kebawah }\end{array}$ & \multirow{3}{*}{\multicolumn{2}{|c|}{$\begin{array}{l}\text { Channels } \\
\text { 1.Direct Marketing } \\
\text { 2.Electronic } \\
\text { Marketing } \\
\text { Pemesanan Online: } \\
\text { 1.Website } \\
\text { 2.Whatsapp } \\
\text { 3.SMS/Telp } \\
\text { 4.Medsos } \\
\text { 5.Forum Jual Beli }\end{array}$}} \\
\hline $\begin{array}{l}\text { Cost Structure } \\
\text { 1.Pembelian } \\
\text { 2.Pengeluaran SDM } \\
\text { 3.Pengiriman } \\
\text { 4.Pajak, Air, Listrik }\end{array}$ & & \multirow{3}{*}{$\begin{array}{l}\text { Customer } \\
\text { Relationship } \\
\text { 1.E-mail } \\
\text { 2.SMS/Telp } \\
\text { 3.Whatsapp } \\
\text { 4.Website } \\
\text { 5.Medsos }\end{array}$} & & \\
\hline \multirow{2}{*}{\multicolumn{2}{|c|}{$\begin{array}{l}\text { Key Resources } \\
\text { 1.Manusia (Staff, Supervisor, Manajer) } \\
\text { 2.Peralatan (Mesin-Mesin, Komputer, Pritner, } \\
\text { Mobil box, Trolley, dsb.) }\end{array}$}} & & & \\
\hline & & & \multicolumn{2}{|c|}{$\begin{array}{l}\text { Revenue Stream } \\
\text { Penjualan Pakaian }\end{array}$} \\
\hline \multicolumn{5}{|l|}{$\begin{array}{l}\text { Value Propositions } \\
\text { 1.Produk Asli Indonesia } \\
\text { 2.Kualitas Pakaian baik } \\
\text { 3..Desain Menarik } \\
\text { 4.Harga terjangkau }\end{array}$} \\
\hline
\end{tabular}

Gambar 3. Business Model Canvas PT Intan Dua

PT Intan Dua memiliki 4 key partners, yaitu supplier kain, toko pakaian, jasa pengiriman dan reseller. Key activities yang dilakukan PT Intan Dua adalah memproduksi pakaian. Customer segment khusus pakaian oblong difokuskan kepada konsumen kelas menengah kebawah. Channels distribusi PT Intan Dua dengan menggunakan direct dan 
electronic marketing, sedangkan pemesanan secar online dapat dilakukan lewat website, whatsapp, sms/telp, medsos, dan forum jual beli. Customer Relationship dapat dijangkau melalui e-mail, website, sms/telp, whatsapp, dan medsos. Key Resource PT Intan Dua ada 2, yaitu manusia dan peralatan. Cost Structure PT Intan Dua ada pada pembelian bahan baku, pengeluaran sdm (gaji, mess, makanan, dsb.), pengiriman produk, Pajak, air, dan listrik. Revenue Stream PT Intan Dua berasal dari penjualan pakaian oblong. Value Propositions yang ditawarkan adalah produk asli Indonesia, kualitas pakaian baik, desain yang menarik, dan harga yang terjangkau.

\section{Marketing Mix}

Product

- Design : Pakaian oblong standar dengan kerah bulat atau V, desain model berupa gambar yang disablon/dijahit timbul.

- Feature : Pakaian oblong dengan desain menarik yang nyaman dikenakan orang Indonesia.

- Quality : Bahan cotton combed 30s, sablon dengan tinta minyak dan air, pola khusus orang Indonesia, jahitan dengan mesin kam, obras, dan biasa.

- Packaging : Plastik bening

Price

- Brand: Intwo Clothing

- List Price : Rp.720.000/Dz, Qty $<50$ Dz

- Payment Period : 7-30 hari

- Payment Method: Cash dan Bank Transfer

- Discount and Allowances:cash discount, volume discount, seasonal discount, quantity discount, dan seasonal allowance.

Place

- Location : Jalan Bandengan Terusan Blok Mawar, RW 1, No. 37, Penjaringan, Jakarta Utara

- Channel : Distribusi \& Supplier

- Coverage: Indonesia

- Inventory: Warehouse dengan kapasitas 20.000 Dz pakaian dan 3.000 roll kain

- Transportation \&Logistics : Internal, Trolley. Eksternal, Mobil Box dan kargo.

Promotion

- Advertisement : Digital media advertising

- Direct Marketing : Pameran

- Sales Promotion :Electronic Promotion(e-mail, socmed, etc.)

- Public Relation : Sponsor kegiatan olahraga dan amal

People

- Personal Selling : delivery salesperson, internal salesperson, external salesperson $(\mathrm{SPG})$

- Customer Service : internal salesperson

- Training : on-the-job training

JIM, Vol. 5, No. 1, Februari 2020, pp.45-56 
Process

- Technological Process : Proses Produksi

- Electronic Process : Proses Pemesanan Secara Online

- Direct Activities : Tanggapan kritik dan saran dari konsumen

- Indirect Activites : Customer Support

Physical Evidence

- Physical Environment : Tidak ada toko, hanya ada kantor (fasilitas yang dapat dikunjungi konsumen)

- Ambience : Kantor memiliki suhu, bau, dan tingkat kebisingan yang cukup baik.

- Spatial Layout : Kantor memiliki ruangan dengan meja, kursi, komputer, dan furniture yang tertata rapih.

- Corporate Branding :Website PT Intan Dua, logo dan brand Intwo Clothing.

\section{3. $\quad$ IFE Matrix}

Setelah didapat data penilaian faktor internal dari reseller, dapat dihitung nilai skor tertimbang dari matriks IFE, dengan perhitungan bobot dengan menggunakan rumus bobot $=\frac{\text { tingkat kepentingan }}{\text { total tingkat kepentingan }}$, dan perhitungan skor tertimbang dengan rumus $=$ Bobot $\mathrm{x}$ Nilai. Pada matriks IFE, penilaian dengan skor $<2,5$ termasuk kepada kelemahan internal perusahaan, sedangkan penilaian dengan skor $>2,5$ termasuk pada kekuatan internal perusahaan.

Tabel 2. Matriks IFE PT Intan Dua

\begin{tabular}{|c|c|c|c|c|}
\hline No. & Faktor Internal & Bobot & Nilai & $\begin{array}{c}\text { Skor } \\
\text { Tertimbang } \\
\end{array}$ \\
\hline \multicolumn{5}{|c|}{ Strengths } \\
\hline 1 & Desain produk & 0.037 & 2.710 & 0.100 \\
\hline 2 & Kelurusan Jahitan & 0.037 & 3.000 & 0.110 \\
\hline 3 & Kekuatan Jahitan & 0.041 & 2.940 & 0.119 \\
\hline 4 & Kehalusan Bahan & 0.032 & 2.650 & 0.086 \\
\hline 5 & Kehalusan Sablon & 0.036 & 2.710 & 0.098 \\
\hline 6 & Harga Produk & 0.047 & 2.880 & 0.135 \\
\hline 7 & Diskon & 0.046 & 3.000 & 0.138 \\
\hline 8 & Ketepatan Waktu Logistik & 0.036 & 2.760 & 0.098 \\
\hline 9 & Keamanan Logistik & 0.038 & 3.060 & 0.117 \\
\hline 10 & Informasi pada Iklan & 0.035 & 2.760 & 0.096 \\
\hline 11 & Sales Promotion & 0.043 & 2.880 & 0.124 \\
\hline 12 & Kemampuan Perusahaan memenuhi Kuantitas & 0.038 & 3.290 & 0.125 \\
\hline 13 & Konsistensi Produk & 0.042 & 3.350 & 0.142 \\
\hline 14 & Fleksibilitas Perusahaan & 0.032 & 2.650 & 0.086 \\
\hline \multirow[t]{2}{*}{15} & Kebijakan Pengembalian Produk & 0.041 & 2.760 & 0.112 \\
\hline & Weakness & & & \\
\hline 1 & Kekuatan Bahan & 0.031 & 2.410 & 0.074 \\
\hline 2 & Popularitas Brand & 0.036 & 2.290 & 0.081 \\
\hline 3 & Kekuatan Packaging & 0.028 & 2.410 & 0.068 \\
\hline 4 & Jangka waktu pembayaran & 0.036 & 2.240 & 0.080 \\
\hline 5 & Kelengkapan Metode pembayaran & 0.039 & 2.000 & 0.079 \\
\hline 6 & Biaya Logistik & 0.041 & 2.470 & 0.102 \\
\hline 7 & Daya Tarik Iklan & 0.031 & 2.470 & 0.075 \\
\hline 8 & Informasi pada Pameran & 0.031 & 2.240 & 0.070 \\
\hline 9 & Pengetahuan Salesperson & 0.034 & 2.410 & 0.083 \\
\hline 10 & Customer Service & 0.046 & 2.180 & 0.101 \\
\hline \multirow[t]{2}{*}{11} & Kemudahan Proses Pemesanan Secara Online & 0.039 & 2.290 & 0.089 \\
\hline & Total & 1.00 & & 2.648 \\
\hline
\end{tabular}

Total nilai tertimbang 2.648 mengindikasikan PT. Intan Dua memiliki posisi internal yang kuat. 


\section{4. $\quad$ EFE Matrix}

Setelah didapat data penilaian dari ancaman dan peluang, dapat dihitung nilai skor tertimbang dari matriks EFE, dengan perhitungan bobot dengan menggunakan rumus bobot $=\frac{\text { tingkat relevansi }}{\text { total tingkat relevansi }}$, dan perhitungan skor tertimbang dengan rumus $=$ Bobot $\mathrm{x}$ Nilai. Nilai merupakan respons dari perusahaan.

Tabel 3. Matriks EFE PT Intan Dua

\begin{tabular}{|c|l|c|c|c|}
\hline No. & \multicolumn{1}{|c|}{ Opportunities } & Bobot & Nilai & $\begin{array}{c}\text { Skor } \\
\text { Tertimbang }\end{array}$ \\
\hline 1 & Perkembangan Teknologi Produksi & 0.099 & 2.670 & 0.264 \\
\hline 2 & Faktor Ekspor & 0.079 & 2.330 & 0.185 \\
\hline 3 & Perkembangan TIK & 0.089 & 3.000 & 0.267 \\
\hline 4 & E-Commerce & 0.139 & 3.330 & 0.462 \\
\hline 5 & Foreign Exchange Rate & 0.079 & 2.330 & 0.185 \\
\hline \multicolumn{1}{|c|}{ Threats } & & & \\
\hline 1 & Faktor Impor dari China & 0.109 & 2.330 & 0.254 \\
\hline 2 & Peraturan Pemerintah & 0.069 & 1.330 & 0.092 \\
\hline 3 & Kenaikan UMR & & 2.330 & 0.138 \\
\hline
\end{tabular}

Tabel 4. Matriks EFE PT Intan Dua (Lanjutan)

\begin{tabular}{|c|l|c|c|c|}
\hline No. & \multicolumn{1}{|c|}{ Opportunities } & Bobot & Nilai & $\begin{array}{c}\text { Skor } \\
\text { Tertimbang }\end{array}$ \\
\hline 4 & Perubahan Teknologi Produksi & 0.079 & 1.670 & 0.132 \\
\hline 5 & Pola Konsumsi & 0.109 & 2.000 & 0.218 \\
\hline 6 & Brand Awareness & 0.089 & 3.000 & 0.267 \\
\hline \multicolumn{2}{|c|}{ Total } & $\mathbf{1 . 0 0 0}$ & & $\mathbf{2 . 4 6 4}$ \\
\hline
\end{tabular}

Total nilai tertimbang sebesar 2.464 mengindikasikan bahwa PT.Intan Dua dibawah rata-rata dalam upayanya untuk menjalankan strategi yang memanfaatkan peluang eksternal dan menghindari ancaman

\section{Analisis Kondisi Perusahaan}

Analisis kondisi perusahaan dilakukan dengan menggunakan diagram SWOT, pada diagram SWOT, sumbu $\mathrm{x}$ dinilai oleh total nilai skor tertimbang matriks IFE, sedangkan sumbu y dinilai oleh total nilai skor tertimbang matriks EFE. 


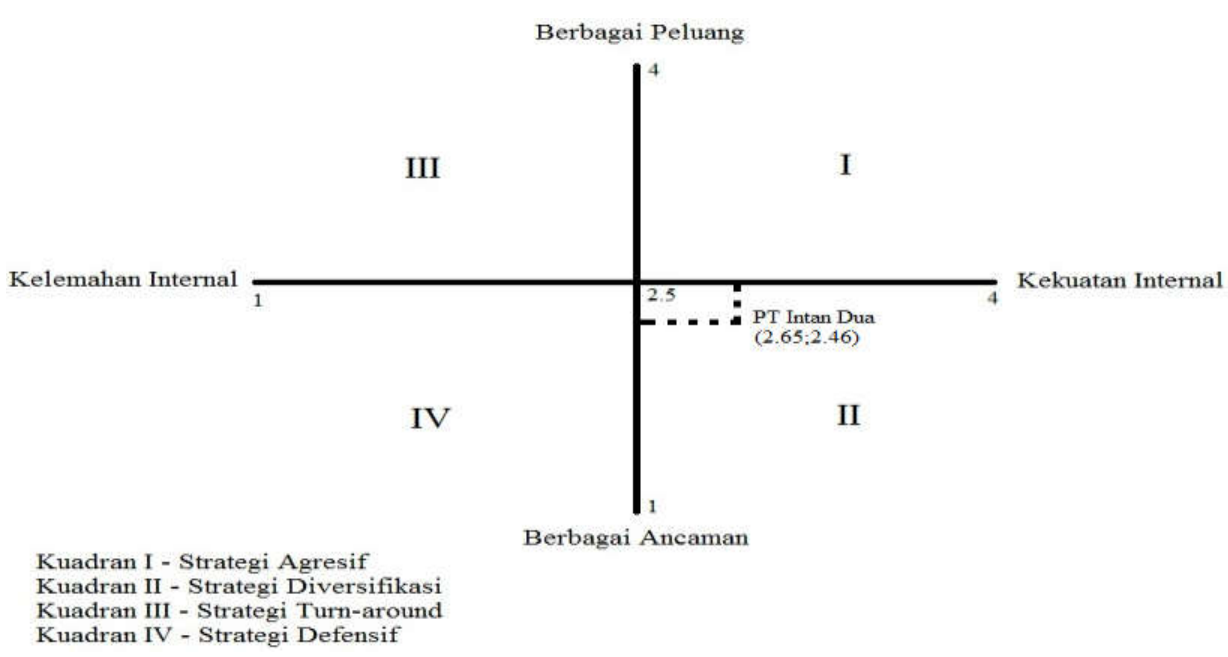

Gambar 4. Diagram SWOT PT Intan Dua

Setelah dilakukan analisis menggunakan diagram SWOT, didapati kondisi PT Intan Dua berada pada kuadran II, dengan koordinat $(2,65 ; 2.46)$, kondisi ini mencerminkan bahwa kekuatan internal perusahaan lebih dominan dibandingkan kelemahannya, akan tetapi ancaman eksternal lebih dominan dibandingkan peluangnya. Strategi yang cocok untuk digunakan pada kondisi ini adalah strategi diversifikasi.

\section{Formulasi Strategi Pemasaran}

Formulasi strategi pemasaran yang sesuai dengan kondisi PT Intan Dua yang terletak pada kuadran II diagram SWOT menurut matriks SWOT adalah strategi ST, yang merupakan strategi pendukung diversifikasi. Berikut adalah strategi yang diformulasikan untuk PT Intan Dua agar dapat meningkatkan penjualan pakaian oblong-nya. 
Tabel 4. Matriks SWOT PT Intan Dua

\begin{tabular}{|c|c|c|}
\hline IFE & $\begin{array}{l}\text { Strength } \\
\text { 1.Desain cukup menarik } \\
\text { 2.Jahitan lurus } \\
\text { 3.Jahitan cukup kuat } \\
\text { 4.Bahan cukup halus } \\
\text { 5.Sablon cukup halus } \\
\text { 6.Harga produk terjangkau } \\
\text { 7.Diskon yang diberikan banyak } \\
\text { 8.Logistik tepat waktu } \\
\text { 9.Logistik aman } \\
\text { 10. Sales promotion baik } \\
\text { 11.Perusahaan mampu memenuhi } \\
\text { demand } \\
\text { 12.Konsistensi produk baik } \\
\text { 13.Perusahaan fleksibel } \\
\text { 14.Kebijakan pengembalian } \\
\text { produk baik }\end{array}$ & $\begin{array}{l}\text { Weakness } \\
\text { 1.Bahan kurang kuat } \\
\text { 2.Brand kurang dikenal } \\
\text { 3.Packaging kurang kuat } \\
\text { 4.Jangka waktu pembayaran } \\
\text { kurang lama } \\
\text { 5.Metode pembayaran kurang } \\
\text { lengkap } \\
\text { 6.Biaya logistik tidak terjangkau } \\
\text { 7.Iklan tidak menarik } \\
\text { 8.Pameran tidak informative } \\
\text { 9.Salesperson } \\
\text { berpengetahuan } \\
\text { 10.Customer service tidak tanggap } \\
\text { 11.Proses pemesanan secara } \\
\text { online sulit } \\
\text { 12.Website tidak menarik }\end{array}$ \\
\hline $\begin{array}{l}\text { Opportunities } \\
\text { 1.Perkembangan Teknologi } \\
\text { Produksi } \\
\text { 2.Peningkatan Faktor Ekspo } \\
\text { Pakaian } \\
\text { 3.Perkembangan Teknologi } \\
\text { Informasi dan Komunikasi } \\
\text { 4.Peningkatan transaksi E- } \\
\text { Commerce } \\
\text { 5.Kenaikan Nilai Tukar US\$ }\end{array}$ & Strategi SO & Strategi WO \\
\hline $\begin{array}{l}\text { Threats } \\
\text { 1.Faktor Impor dari China } \\
(0.254) \\
\text { 2.Peraturan Pemerintah } \\
(0.092) \\
\text { 3.Kenaikan UMR }(0.138) \\
\text { 4.Perubahan Teknologi } \\
\text { Produksi }(0.132) \\
\text { 5.Pola Konsumsi }(0.218) \\
\text { 6.Brand Awareness }(0.267)\end{array}$ & $\begin{array}{c}\text { Strategi ST/ } / \\
\text { 1. S2,S3,S4,S5-T1 } \\
\text { 2. S7,S10-T5 } \\
\text { 3. S1,S2,S3,S4,S5,S6-T6 }\end{array}$ & Strategi WT \\
\hline
\end{tabular}

1.Strategi meningkatkan kualitas pakaian oblong (S2,S3,S4,S5-T1)

Ancaman produk impor dari China dikarenakan harga produk tersebut yang relatif lebih murah, PT Intan Dua dapat melawan ancaman ini dengan aspek kualitas pakaian yang lebih baik dari pakaian impor tersebut. PT Intan Dua dapat meningkatkan kualitas pakaiannya dengan meningkatkan kekuatan bahan pakaian oblongnya, caranya adalah dengan mengganti bahan baku pakaian oblong dengan kain campuran cotton dan sedikit polyester.

2. Strategi membangun motivasi beli reseller (S7,S10-T5)

Salah satu faktor yang berpengaruh dalam pola konsumsi produk adalah motivasi beli. Pemberian motivasi dapat dilakukan secara langsung (Direct Motivation) oleh perusahaan dengan berbagai cara, salah satu caranya adalah dengan pemberian sales promotion. PT Intan Dua dapat meningkatkan sales promotion yang diberikan dengan cara menambah pekerja internal salesperson yang saat ini hanya berjumlah 1 orang.

3.Strategi membanguncitra produk (S1,S2,S3,S4,S5,S6-T6)

Peningkatan brand awarenessdi kalangan merupakan ancaman bagi PT Intan Dua, karena brand usutan PT Intan Dua dinilai masih kurang dipercaya, sehingga PT Intan Dua harus membangun citra produknya agar brand-nya dapat dipercaya oleh masyarakat, salah satu cara yang dapat dilakukan PT Intan Dua untuk 
meningkatkan citra produknya adalah membuat desain orisinil yang memiliki karakteristik tentang PT Intan Dua, sehingga jika orang melihat desain tersebut, dapat diketahui bahwa produk tersebut merupakan brand Intwo Clothing

\section{Business Model Canvas setelah Formulasi strategi}

Setelah dilakukan formulasi strategi pada PT Intan Dua, terdapat perubahan pada business model canvas-nya, perubahan terjadi pada value propositions, dengan adanya formulasi strategi value propositions yang ditawarkan kepada konsumen akan lebih banyak.

\begin{tabular}{|c|c|c|c|c|}
\hline Business Model Canvas & $\begin{array}{l}\text { Designed for: } \\
\text { PT Intan Dua }\end{array}$ & $\begin{array}{l}\text { Designed by: } \\
\text { Huanche Wilson }\end{array}$ & $\begin{array}{c}\text { Date: } \\
06 / 01 / 19\end{array}$ & $\begin{array}{c}\text { Version } \\
2.0\end{array}$ \\
\hline $\begin{array}{l}\text { Key Partners } \\
\text { 1.Supplier Kain } \\
\text { 2.Toko Pakaian } \\
\text { 3.Jasa Pengiriman } \\
\text { 4.Reseller }\end{array}$ & \multirow{2}{*}{$\begin{array}{l}\text { Key Activites } \\
\text { Produksi } \\
\text { Pakaian: } \\
\text { 1.Beli Bahan } \\
\text { Baku } \\
\text { 2.Potong Pola } \\
\text { 3.Sablon } \\
\text { 4.Jahit } \\
\text { 5.Setrika } \\
\text { 6.Packing }\end{array}$} & $\begin{array}{l}\text { Customer } \\
\text { Segment } \\
\text { Konsumen kelas } \\
\text { menengah } \\
\text { kebawah }\end{array}$ & \multicolumn{2}{|c|}{$\begin{array}{l}\text { Channels } \\
\text { 1.Direct Marketing } \\
\text { 2.Electronic } \\
\text { Marketing }\end{array}$} \\
\hline $\begin{array}{l}\text { Cost Structure } \\
\text { 1.Pembelian } \\
\text { 2.Pengeluaran SDM } \\
\text { 3.Pengiriman } \\
\text { 4.Pajak, Air, Listrik }\end{array}$ & & \multirow{3}{*}{$\begin{array}{l}\text { Customer } \\
\text { Relationship } \\
\text { 1.E-mail } \\
\text { 2.SMS/Telp } \\
\text { 3.Whatsapp } \\
\text { 4.Website } \\
\text { 5.Medsos }\end{array}$} & \multirow{2}{*}{\multicolumn{2}{|c|}{$\begin{array}{l}\text { Pemesanan Online: } \\
\text { 1.Website } \\
\text { 2.Whatsapp } \\
\text { 3.SMS/Telp } \\
\text { 4.Medsos } \\
\text { 5.Forum Jual Beli }\end{array}$}} \\
\hline \multirow{2}{*}{\multicolumn{2}{|c|}{$\begin{array}{l}\text { Key Resources } \\
\text { 1.Manusia (Staff, Supervisor, Manajer) } \\
\text { 2.Peralatan (Mesin-Mesin, Komputer, Pritner, } \\
\text { Mobil box, Trolley, dsb.) }\end{array}$}} & & & \\
\hline & & & \multicolumn{2}{|c|}{$\begin{array}{l}\text { Revenue Stream } \\
\text { Penjualan Pakaian }\end{array}$} \\
\hline \multicolumn{5}{|c|}{$\begin{array}{l}\text { Value Propositions } \\
\text { 1.Produk Asli Indonesia } \\
\text { 2.Kualitas Pakaian baik } \\
\text { 3..Desain Menarik dan memiliki } \\
\text { karakteristik yang orisinil } \\
\text { 4.Harga terjangkau }\end{array}$} \\
\hline
\end{tabular}

Gambar 5.Business Model Canvas PT Intan Dua setelah formulasi strategi

\section{KESIMPULAN}

1. Nilai total skor tertimbang matriks IFE PT Intan Dua sebesar 2.648, dan nilai total skor tertimbang matriks EFE PT Intan Dua sebesar 2.464.

2. Kondisi PT Intan Dua saat ini terdapat pada kuadran II diagram SWOT

3. Strategi yang tepat, sesuai dengan kondisi perusahaan untuk meningkatkan penjualan pakaian oblong adalah strategi ST (Strength-Threat), yang berupa peningkatan kualitas pakaian oblong, membangun motivasi beli, dan membangun citra produk

\section{DAFTAR PUSTAKA}

Ali, Hasan. 2013. Marketing dan Kasus-Kasus Pilihan. Yogyakarta: CAPS.

Alma, Buchari. 2016. Manajemen Pemasaran dan Pemasaran Jasa. Bandung: Alfabeta. Assauri, Sofjan. 2013. Manajemen Pemasaran. Jakarata: Rajawali Pers.

Boone, Louis E. Kurtz, David L. 2013. Pengantar Bisnis Kontemporer edisi 13. Jakarta: Salemba Empat. 
David, Fred R. 2013. Manajemen Strategi edisi 15. Jakarta: Salemba Empat.

Ferrel, O.C. 2016. Marketing : Concept and Strategies $7^{\text {th }}$ edition. London: Cengage Learning EMEA.

Gomes, Faustion Cardoso. 2013. Manajemen Sumber Daya Manusia. Yogyakarta: Andi.

J.Setiadi, Nugroho. 2018. Perilaku Konsumen : Konsep dan Implikasi untuk Strategi dan Penelitian Pemasaran edisi Revisi. Jakarta: PT Kencana.

Jogiyanto. 2014. Analisis dan Desain Sistem Informasi. Yogyakarta: Andi.

Kasmir. 2014. Analisis Laporan Keuangan edisi 1 cetakan 7. Jakarta: Ragrafindo Perkasa.

Kotler, Phillip. 2013. Manajemen Pemasaran, Analisis Perencanaan dan Pengendalian edisi 13. Jakarta: Prehallindo.

Kotler, Phillip dan Gary Armstrong. 2014. Principle of Marketing $15^{\text {th }}$ edition. New Jersey: Pearson.

Kotler, Phillip dan Kevin L. Keller. 2016. Marketing Management $16^{\text {th }}$ edition. New Jersey: Pearson.

Li, Xian Guo. 2011. Corporate-, Product-, and User-Image Dimension and Purchase Intentions. China: Journal of Computerism.

Osterwalder, Alexander dan Yves Pigneur. 2010. Business Model Generation : A Handbook for Visionaries, Game Changers, and Challengers. Chichester: John Wiley and Sons Ltd.

Rangkuti, Freddy. 2014. Analisis SWOT : Teknik Membedah Kasus Bisnis. Jakarta: Gramedia.

Swastha, Basu Dharmmesta. 2014. Manajemen Pemasaran. Yogyakarta: BPFE.

Zeithaml, V.A., M.J. Bitner. dan D.D. Gremler. 2013. Services Marketing : Integrating Customer Focus Across the Firm $6^{\text {th }}$ edition. Boston: Mc.Graw-Hill 